\title{
FAKTOR-FAKTOR YANG MEMPENGARUHI PROGRAM TRANSMIGRASI TERHADAP TINGKAT KESEJAHTERAAN PENDUDUK TRANSMIGRAN
}

\author{
Chintya Rachman, Tiara Noviarini \\ STIE Tribuana Bekasi, STMIK Mikar
}

\begin{abstract}
ABSTRAK
Penelitian ini bertujuan untuk mengetahui tingkat kesejahteraan dan faktor yang mempengaruhi tingkat kesejahteraan warga serta faktor yang berkontribusi dari program transmigrasi terhadap kesejahteraan warga transmigran. Kedua untuk mengetahui faktor yang mempengaruhi perkembangan tingkat kesejahteraan warga transmigran pada lokasi transmigrasi dari sebelum mereka menjadi warga transmigran dan setelah mereka menjadi warga transmigran. Metode penelitian yang digunakan dalam penelitian ini adalah teknik survei lapangan yaitu pengumpulan data kuantitatif dengan menggunakan kuesioner. Hasil penelitian menunjukkan warga transmigrasi masih tergolong ke dalam kategori kurang mampu. Kategori kurang mampu ini disebabkan masyarakat pendapatan utamanya masih dari menjadi buruh serabutan dan bertani yang mereka miliki belum memiliki hasil karena belum masuk pada masa sadap.

Kata kunci: Program Transmigrasi, kesejahteraan.
\end{abstract}

\section{PENDAHULUAN}

Transmigrasi

merupakan

perpindahan penduduk secara sukarela untuk meningkatkan kesejahteraan dan menetap di kawasan transmigrasi yang diselenggarakan oleh Pemerintah (UU No. 29 tahun 2009). Kita ketahui bahwa di belahan bumi ini, perpindahan penduduk mampu menyumbang kontribusi pada pembangunan sosial dan ekonomi 'untuk memungkinkan dalam mengatasi "kekejaman ruang," yang menjadi objek utama kebijaksanaan tentang ilmu kewilayahan (Brown, 1977). Noviarini
(2018), mengatakan bahwa para transmigran membawa budaya dan bahasa masing-masing sehingga tidak menjadikan kepunahan budaya dan Bahasa asal.

Martono (1986), mengemukakan bahwa apabila dilihat dari definisi secara demografi, transmigrasi merupakan bagian dari migrasi yang salah satu komponennya terjadi perubahan atau pertumbuhan penduduk dengan tujuan pembangunan. Dengan kata lain, transmigrasi merupakan perpindahan penduduk dari suat wilayah ke wilayah lain dalam rangka 
pembentukan masyarakat baru untuk membantu pembangunan baik bagi daerah yang didatangi ataupun yang ditinggalkan dalam rangka pembangunan nasional. Pelaksanaan program transmigrasi tidak dapat dihindarkan bahwa telah banyak membantu masyarakat kurang mampu di daerah asalnya menjadi masyarakat yang sudah berada di daerah transmigrasi. Para transmigran dibimbing dalam membangun kehidupannya agar dalam waktu singkat mereka dapat mencapai suatu penghidupan yang layak di dearah baru.

Pemerintah mengupayakan jenisjenis transmigrasi yaitu transmigrasi umum, transmigrasi swakarsa atau transmigrasi spontan, dan transmigrasi lokal. Transmigrasi umum adalah transmigrasi dimana semua biaya untuk transmigrasi adalah ditanggung oleh pemerintah. Transmigrasi swakarsa atau transmigrasi spontan adalah transmigrasi yang dilakukan penduduk dengan sebagian biaya ditanggung sendiri tetapi masih diatur oleh pemerintah. Transmigrasi lokal adalah pemindahan penduduk dari suatu wilayah ke wilayah lain yang masih satu
Pemerintahan Daerah Provinsi (Arman, 2006).

Transmigrasi lokal mencakup migrasi dalam daerah tertentu, dari daerah satu ke daerah yang lain. Migrasi ini terasa agak berat bagi para transmigran akibat pembagian bidang tanah yang terlalu kecil sebelum perang. Oleh karena itu, generasi muda bahkan kadang-kadang para transmigran itu sendiri sesudah beberapa tahun merasa kekurangan tanah lagi. Mengurangnya kesuburan daerah-daerah yang tidak beririgasi sehingga panen menurun, juga turut menyebabkan terjadinya kekurangan tanah ini sehingga adanya orang-orang yang tidak memiliki tanah. Mereka itu lalu mencari penghidupannya dengan mengolah tanah orang lain. Namun jalan keluar lainnya lebih terbuka yakni, pindah ke daerah-daerah yang baru dibuka di daerahnya. Acap kali hal ini berlangsung secara ilegal. Mereka lantas disebut anak kolonis. Istilah resmi untuk mereka adalah transmigran lokal (H.J Heeren:1979). Tingkat perannya, transmigrasi dibagi menjadi 3 (tiga) model, yaitu : 


\section{1) Transmigrasi model ring $I$} merupaka penempatan mobilitas penduduk antar Kecamatan dalam satu wilayah pemerintah Kabupaten/Kota.

2) Transmigrasi model ring II yaitu penempatan mobilitas penduduk antar Kabupaten dalam wilayah pemerintah Provinsi.

3) Transmigrasi model ring III ialah penempatan mobilitas penduduk antar provinsi dalam wilayah negara kesatuan Republik Indonesia.

Menurut Martono (1986), dalam Singarimbun dan Swasono (1986), apabila dilihat secara demografi, transmigrasi dipandang sebagai suatu upaya untuk mencapai keseimbangan penyebaran penduduk, juga dimaksudkan untuk menciptakan perluasan kesempatan kerja. Transmigrasi ini juga dinilai membantu mempercepat terwujudnya trilogi pembangunan, yaitu pemerataan pembangunan dan hasil-hasilnya menuju tercapainya keadilan sosial bagi seluruh rakyat, pertumbuhan ekonomi yang cukup tinggi, serta stabilitas nasional yang sehat dan dinamis.
Paradigma baru transmigrasi tidak sekadar memindahkan penduduk dari daerah yang padat penduduk ke daerah yang masih kekurangan penduduk. Lebih dari itu, transmigrasi menjadi cara bagi masyarakat untuk meningkatkan kesejahteraan hidupnya, sekaligus sebagai usaha membangun ketahanan pangan (Suparno, 2007).

Kebijakan transmigrasi diarahkan pada tiga hal pokok yaitu :

1) Ikut serta dalam penanggulangan kemiskinan yang disebabkan oleh ketidak berdayaan penduduk untuk memperoleh tempat tinggal yang layak.

2) Memberi peluang berusaha dan kesempatan kerja kepada masyarakat.

3) Memfasilitasi pemerintah daerah dan masyarakat untuk melaksanakan perpindahan penduduk dan mendukung pemberdayaan potensi sumber daya wilayah, kawasan dan lokasi yang pemanfaatannya kurang optimal agar berkembang lebih produktif.

Sistem penyelenggaraan transmigrasi nasional dengan paradigma 
baru dilatarbelakangi oleh lima pokok pikiran, yaitu:

1) Pertama, pembangunan transmigrasi sebagai upaya rekayasa ruang dan orang, diarahkan untuk mendukung ketahanan pangan dan kebutuhan papan nasional.

2) Kedua, pengembangan usaha dan budidaya di permukiman transmigrasi diarahkan untuk mendukung kebijakan energi alternatif dengan mengembangkan budidaya tanaman bahan bio-energi seperti kelapa sawit, jagung, tebu, singkong, dan juga jarak pagar.

3) Ketiga, pembangunan permukiman transmigrasi diarahkan untuk mengembangkan daerah perbatasan, pulau terluar, daerah tertinggal dan terisolir, merupakan upaya mengurangi kesenjangan antar wilayah sebagai bagian dari upaya mendukung ketahanan nasional.

4) Keempat, pembangunan transmigrasi sebagai upaya pengembangan wilayah baru perlu dilaksanakan secara kolaboratif dengan kalangan swasta untuk mengembangkan investasi, sehingga transmigrasi akan mampu mendukung pemerataan investasi, dan

5) Kelima, pembangunan transmigrasi sebagai salah satu upaya penyediaan tempat tinggal, tempat bekerja, dan tempat berusaha merupakan salah satu strategi nasional mengatasi pengangguran dan kemiskinan secara berkelanjutan.

Pelaksanaan program transmigrasi tidak dapat dipungkiri telah banyak membantu masyarakat kurang mampu di daerah asalnya menjadi masyarakat yang sudah agak berada di daerah transmigrasi, sekurang-kurangnya sudah dapat memenuhi kebutuhan hidup sehari-hari tanpa bantuan atau tergantung kepada orang lain, atau tergantung kepada orang tua di daerah asalnya. Transmigrasi juga sudah banyak mendorong dalam peningkatan kesejahteraan masyarakat yang terlibat di dalamnya.

Tingkat kesejahteraan adalah merupakan konsep yang digunakan untuk menyatakan kualitas hidup seseorang pada suatu wilayah pada 
kurun waktu tertentu. Konsep kesejahteraan memiliki sifat relatif, yaitu tergantung bagaimana penilaian masing-masing individu terhadap kesejahteraan itu sendiri. Keadaan sejahtera yang dimiliki seseorang dapat berbeda dengan keadaan sejahtera orang lain. Terpenuhinya kebutuhan makan nasi tiap hari untuk seorang buruh adalah dapat dikatakan sejahtera, namun lain halnya dengan seorang pengusaha besar (Pangemanan, 1996).

Menurut Yosep (1996) dalam Saharti (1998), definisi kesejahteraan mencakup dua pendekatan yaitu pendekatan makro dan pedekatan mikro. Pendekatan makro memandang bahwa kesejahteraan dapat dinyatakan dengan indikator-indikator yang telah disepakati secara ilmiah, sehingga ukuran kesejahteraan masyarakat berdasarkan data-data empiris suatu masyarakat. Pendekatan makro ini disebut juga pendekatan makro objektif karena mencakup keadaan kesejahteraan suatu wilayah, negara atau provinsi. Dari beberapa pernyataan di atas maka penelitian ini bertujuan:

1) Mengetahui tingkat kesejahteraan dan faktor yang mempengaruhi tingkat kesejahteraan serta faktor yang berkontribusi dari program transmigrasi terhadap kesejahteraan masyarakat transmigran di lokasi transmigrasi di Kabupaten Pringsewu, Lampung.

2) Mengetahui faktor yang mempengaruhi perkembangan tingkat kesejahteraan warga transmigran di lokasi transmigrasi di Kabupaten Pringsewu, Lampung dari sebelum mereka menjadi warga transmigran dan setelah mereka menjadi warga transmigran.

Program transmigrasi ini juga efektif kesuksesan usaha-usaha dalam pembangunan daerah, karena transmigrasi ini memindahkan penduduk pada daerah yang pada dahulunya belum diolah. Pada dasanya tujuan utama dari transmigrasi adalah penyebaran jumlah penduduk agar tidak menumpuk pada satu daerah saja dan membuka kegiatan ekonomi didaerah lain. Transmigrasi juga dapat mempercepat perkembangan wilayah yang tertinggal karena dengan adanya transmigrasi maka akses terhadap wilayah tersebut terbuka seperti akses terhadap pendidikan, ekonomi dan 
teknologi menjadi mudah diakses. pada jaman otonomi daerah seperti sekarang ini transmigrasi tidak hanya dilakukan untuk melakukan persebaran penduduk namun juga untuk peningkatan kesejahteraan masyarakat seperti mengurangi kemiskinan dengan cara perluasan lapangan kerja dibidang pertanian, perkebunan dan yang lainya yang termasuk dalam pengelolaan alam.

\section{METODE PENELITIAN}

Penelitian

dilakukan

Transmigrasi, Kabupaten Pringsewu, Lampung. Dalam penelitian ini metode yang digunakan adalah teknik survei lapangaan yaitu pengumpulan data kuantitatif dengan menggunakan kuesioner, dan penelusuran dokumen yang relevan dengan topik penelitian. Penelusuran dokumen-dokumen yang dianggap memberikan informasi dilakukan di kantor Disdukcapil sebagai bahan gambaran umum lokasi penelitian.

Dalam melakukan penelitian, peneliti memperhatikan variabel penelitian. Variabel yang digunakan adalah dua jenis variabel, variabel yang mempengaruhi dan variabel yang dipengaruhi. Merujuk pada pernyataan Tjiptoherijanto (1986), hal yang harus diperhatikan dalam menilai perkembangan program transmigrasi adalah: pendapatan warga transmigran yang merupakan variabel yang mempengaruhi dalam penelitian ini. Variabel yang dipengaruhi dalam penelitian ini adalah variabel kesejahteraan yang membentuk jiwa warga transmigran yang mandiri. Variable kesejahteraan warga transmigrasi diukur dari tingkat persentase pendapatan yang dikurangi oleh pengeluaran untuk memenuhi kebutuhan hidup warga.

Data yang digunakan adalah data primer dan data sekunder. Data primer mencakup semua data yang berkenaan dengan variabel pengaruh dan variabel terpengaruh. Data primer juga mencakup data yang didapat dari hasil observasi dan hasil wawancara dengan warga transmigran.

Data sekunder yang dikumpulkan mencakup semua data yang diambil dan ditelusuri dari dokumen Disdukcapil Kabupaten Pringsewu, Lampung dan dokumen lain yang dipandang mendukung penelitian ini. 


\section{HASIL DAN PEMBAHASAN}

\subsection{Tingkat Kesejahteraan}

\section{Masyarakat Transmigrasi}

Program Transmigrasi di UPT Tanjung Kukuh dimulai pada tahun 2009, Program transmigrasi menggabungkan masyarakat tranmigran yang berbeda kultur sehingga kecemburuan sosial dan konflik antara warga trans dapat diminimalisir di tempat permukiman. Penggabungan masyarakat ini tidak menimbulkan kecemburuan antara masyarakat karena dalam di lokasi mereka senasib dan diperlakukan sama dan tidak ada pembedaan dari awal masuk, selama di lokasi haknya sama dana dil.

Masyarakat Transmigrasi dibina dalam Program pembinaan dan pembangunan desa transmigrasi yang bertujuan untuk meningkatkan kehidupan sosial-ekonomi dan budaya masyarakat transmigrasi, sehingga mereka dapat memenuhi semua kebutuhan hidup baik kebutuhan sandang, pangan dan papan. Selain itu program ini bertujuan untuk mengatasi masalah kemiskinan, kekurangan tenaga kerja, dan pembukaan lahan pertanian baru dalam upaya pemanfaatan sumber daya alam untuk tujuan mencapai masyarakat yang sejahtera.

UPT ini dibangun di atas tanah milik Desa Tanjung Kukuh yang dibebaskan lahannya oleh Gubernur Sumatera Selatan pada saat itu dan diberikan mandat kepada Bupati untuk didirikan UPT. UPT ini terletak pada bagian selatan Desa Tanjung Kukuh yang berbatasan dengan Desa Taman Mulyo sedangkan daerah timur dan baratnya masih sebagian besar kawasan Desa Tanjung Kukuh, hal ini dikarenakan luas dari UPT Tanjung Kukuh ini hanyalah 180 hektar sedangkan Desa Tanjung Kukuh sendiri adalah desa yang luas.

Kebijakan pemerintah untuk melakukan program transmigrasi ini adalah untuk mengurangi angka kemiskinan dan mendorong masyarakat menuju hidup sejahter. Said (1995) melakukan penilaian mengenai tingkat kemiskinan (kaitannya dengan kemampuan dalam memenuhi kebutuhan hidup) ditentukan berdasarkan beberapa pengkategorian. Pengklasifikasian kemiskinan tersebut diantaranya: 
1. Miskin sekali, yaitu daerah-daerah yang pendapatan per kapita penduduknya di bawah $75 \%$ dari kebutuhan hidup minimum.

2. Miskin, yaitu daerah-daerah yang pendapatan per kapita penduduknya $25 \%$ kurang atau tepat di "garis kemiskinan" atau $25 \%$ tepat pada kebutuhan hidup minimum.

3. Hampir miskin, adalah daerahdaerah yang pendapatan per kapita penduduknya $25 \%$ lebih dari kebutuhan hidup minimum sampai dengan mencapai kebutuhan hidup sekunder (200\%).

4. Tidak miskin, yaitu daerah-daerah yang pendapatan per kapita penduduknya melebihi kebutuhan pokok hidup sekunder.

Namun dalam hal ini penilain ini hanya dijadikan tolak ukur untuk menentukan apakah warga transmigrasi di lokasi UPT Tanjung Kukuh ini sudah dikatakan sejahtera atau belum. Data yang dipakai adalah data pendapatan keseluruhan dari warga transmigrasi yang dikurangkan dengan total pengeluaran mereka dalam satu bulannya, dari perhitungan ini dapat kita simpulkan apakah warga transmigrasi sudah sejahtera atau belum mencapai kata sejahtera. Perhitungan lebih rinci dapat dilihat pada tabel di bawah.

Untuk melihat seberapa besar persentase pendapatan di atas pengeluaran masyarakat transmigrasi dapat kita lihat pada tabel dibawah.

Dilihat dari hasil perhitungan pada tabel maka warga UPT tanjung kukuh masih tergolong pada masyarakat yang miskin namun di sini angka persentasenya hampir menunjukkan bahwa warga dapat di golongan hampir miskin dikarenakan angka persentasenya mencapai $21.89 \%$.

Lahan pertanian yang belum bisa menghasilkan pendapatan serta pekerjaan sebagian besar warga transmigran sebagai buruh serabutan ini yang membuat mereka berada pada garis kemiskinan. Namun walau halnya demikian mereka dapat bertahan hidup di lokasi transmigrasi dan dapat memenuhi kebutuhan hidup mereka sehari-hari.

Hampir tidak miskinnya warga transmigrasi ini juga di dukung oleh fakta lain seperti bangun fisik rumah 
yang baik. Dapat dilihat dari fisik rumah yang masih berdiri kokoh dengan lantai yang sudah di semen, penerangan rumah sudah dari listrik, adanya fasilitas tempat buang air besar pada setiap rumahnya serta dari hal lain seperti memasak yang hampir keseluruhan sudah menggunakan gas elpiji, mampu makan 3 kali dalam sehari serta mampu membeli pakaian 2 kali dalam setahunnya dan yang lebih terlihat bahwa warga sudah beranjak dari kemiskinan adalah mereka memiliki aset seperti motor dan barang-barang elektronik seperti pada.

Namun, ukuran tingkat kesejahteraan warga transmigrasi sendiri tidak dapat menggambarkan seberapa jauh atau tinggi tingkat kesejahteraan mereka, kita tentu harus juga melihat faktor apa saja yang mempengaruhi tingkat kesejehteraan itu, tidak mungkin suatu warga atau masyarakat kita katakan sejahtera tanpa memandang sisi-sisi yang mempengaruhinya.

\subsection{Faktor Yang Mempengaruhi} Tingkat Kesejahteraan Warga Transmigrasi
Pendapatan adalah faktor yang paling diperhatikan kaitannya dengan kesejahteraan warga transmigran. Pendapatan merupakan gambaran upaya pencapaian berbagai kebutuhan hidup warga transmigran yang ada di UPT Tanjung Kukuh. Pendapatan warga tersebut diukur melalui seberapa besar warga transmigran dapat menghasilkan uang dalam periode perbulannya. Dalam pengkategorian, terdapat tiga kategori yaitu: pendapatan rendah, sedang, dan tinggi. Pendapatan rendah yang diperoleh warga transmigran yaitu berkisar di bawah pendapatan rata-rata warga transmigran, sebesar Rp.1082222,-. Pendapatan rata-rata ini dilihat dari pengakumulasian seluruh pendapatan yang diperoleh warga lalu dirata-ratakan dengan dibagi oleh jumlah KK. Untuk melihat pengkategorian tingkat pendapatan warga transmigran, dapat dilihat pada tabel berikut ini.

Jika dilihat dari pembagian kelas pendapatan pada warga Transmigrasi maka kebanyakan warga memiliki pendapatan yang berada pada kelas 
rendah dan sedang yakni: $40 \%$ dan $44,4 \%$, sedangkan yang berpendapatan tinggi cenderung lebih sedikit yakni, hanya $15,6 \%$.

Warga transmigran benar-benar memanfaatkan lahan yang diberikan dan menanam tanaman yang dianjurkan oleh petugas lapangan. Bibit tanaman yang dianjurkan merupakan bantuan langsung dari pemerintah daerah Kabupaten OKU Timur dan merupakan pembiayaan yang telahdianggarkan oleh pemerintah pusat (APBD dan APBN).

Ada juga yang memiliki pendapatan dari bertani sembari meunggu hasil dari serabutan, mereka yakni kebanyakan menanam cabe, ubi dan jagung. Untuk menutupi kebutuhan mereka jika mereka tidak bekerja sebagai buruh serabutan dan hasil dari pertanian inilah yang mereka gunakan untuk biaya mereka bertahan hidup di lokasi transmigrasi.

Perhitungan korelasi spearman juga menunjukkan adanya hubungan antara pendapatan dengan kesejahteraan warga transmigran, hal ini dapat dilihat dari perhitungan korelasi spearman pada tabel di bawah ini.
Angka korelasi antara tingkat pendapatan dengan tingkat kesejahteraan adalah 0,536 (korelasi Spearman) atau dalam hal ini dapat dikatakan cukup kuat. Hal ini berarti, arah hubungan antara tingkat pendapatan dengan tingkat kesejahteraan adalah positif, atau semakin tinggi tingkat pendapatan maka masyarakat transmigran akan semakin tinggi tingkat kesejahteraannya.

$\begin{array}{rrr}\text { Korelasi } & \text { antara } & \text { tingkat } \\ \text { pendapatan } & \text { dengan } & \text { tingkat }\end{array}$
kesejahteraan adalah signifikan, karena angka probabilitas atau Sig. adalah 0,000 jauh di bawah 0,05. Hal ini berarti, sesungguhnya antara variabel tingkat pendapatan dan tingkat kesejahteraan ada hubungan, atau tingkat kesejahteraan dipengaruhi oleh tingkat pendapatan.

\subsection{Faktor Yang Berkontribusi Dari Program Transmigrasi Terhadap} Kesejahteraan Warga Transmigran

\section{Kelembagaan Sosial}

Sistem kelembagaan dalam konteks UPT Tanjung Kukuh diartikan sebagai sistem yang berlaku dikalangan warga transmigran. Warga transmigran, 
kaitannya dengan sistem nilai budaya orang Indonesia, mengandung empat konsep (Koentjaraningrat, 2004). Empat konsep tersebut diantaranya; manusia tidak hidup sendiri, bergantung pada orang lain, memelihara hubungan baik, dan berbuat sama dengan sesamanya dalam suatu komunitas.

Merujuk pada empat konsep tersebut, dalam proses pengembangan UPT diperlukan adanya keeratan warga (ke-solid-an) sebagai komunitas transmigran dan juga komunitas petani yang mana keeratan warga ini dimaksudkan agar pada proses pembangunan dan pengembangan UPT dapat dilakukan secara bersama-sama untuk kepentingan bersama. Meski umur UPT Tanjung Kukuh baru meninjak umur yang ke-6, ternyata dalam proses mempersatukan warga untuk proses pengembangan dan pembangunan UPT tidaklah sulit untuk dilakukan karena warga sadar akan tanggung jawab dan tujuan hidup mereka di UPT. Diantaranya masih saja ada warga yang masih bersikap kurang mau bekerjasama atau berbuat sama dengan warga lain namun hal ini tidak menghambat suatu kelambagaan sosial karena walau terlihat ogah-ogah tapi mereka tetap ikut serta dalam suatu sistem kelembagaan sosial.

Semua sistem kelembagaan yang ada pada UPT Tanjung Kukuh ini terbilang solid karena dari beberapa sistem kelembagaan sosial diadakan minimal satu kali dalam satu minggu, hanya kumpulan untuk menyambut hari raya yang dilakukan beberapa hari saja sebelum hari raya itu tiba namun sudah 5 tahun ini warga rutin melakukannya di setiap menjelang hari raya tiba.

\section{Kesehatan}

Tjiptoherijanto

mengemukakan bahwa kesehatan merupakan salah satu tolak ukur keberhasilan program transmigrasi. Kondisi kesehatan wagra transmigran mempengaruhi kualitas hidup warga transmigran itu sendiri. Membaiknya tingkat kesehatan warga transmigran akan menunjukan nilai kualitas hidup dan keberhasilan progran transmigrasi.

Tabel di atas menggambarkan bahwa di UPT Tanjung Kukuh masih terlihat adanya warga yang berada pada kategori tidak sehat. Kondisi demikian 
memang sangat mungkin terjadi pada suatu lokasi UPT. Dengan kondisi fasilitas yang seadanya, dalam artian tidak selengkap kondisi fasilitas yang ada di kota, memungkinkan warga sulit untuk memanfaatkan inovasi dalam bidang kesehatan. Meski dengan fasilitas "seadanya", warga tetap menjaga kesehatannya berbekal pengetahuan yang didapat dari pendampingan yang diselenggarakan tiap bulan.

Selain mendapatkan pengetahuan tentang menjaga ksesehatan, di lokasi UPT Tanjung Kukuh juga terdapat dua Bidan jaga yang yang di tempatkan oleh pemerintah Kabupaten Pringsewu, Lampung dan Dinas Penduduk dan Pencatatan SIpil pada UPT untuk terus menjaga dan meningkatkan taraf kesehatan warga. Hal ini dapat dilihat pada tabel di atas dimana 16 warga dari 17 warga yang sakit dapat langsung mendapatkan pengobatan.

\section{Keamanan}

Tjiptoherijanto

mengemukakan bahwa kondisi UPT yang aman dapat membuat warga transmigran merasa betah untuk tinggal di UPT. Meski keamanan dan intensitas kriminalitas di suatu UPT sulit untuk diketahui dan diukur secara pasti, tapi minimalnya kondisi keamanan UPT dapat dilihat secara keseluruhan dalam keberhasilan program dengan beberapa informasi yang dapat diyakini sebagai nilai keamanan. Misalnya, rendah atau tidak adanya warga yang merasa disakiti secara fisik, tidak adanya warga yang merasa kehilangan barang, tidak adanya warga yang merasa jiwanya tertekan, dan tidak adanya hak warga transmigran yang diambil secara paksa, adalah merupakan informasi bahwa UPT merupakan tempat yang aman sebagai tempat tinggal. Warga transmigran yang tidak merasa aman tinggal di UPT akan pergi dari UPT. Untuk itu, keamanan warga yang tinggal di UPT haruslah diperhatikan.

Keadaan keamanan lokasi UPT Tanjung Kukuh dapat dikatakan aman karena semua warga berpartisipasi dalam menjaga keamanan terutama pada malam hari, setiap malam warga melakukan ronda secara bergiliran untuk menghindari suatu tindakan kriminalitas. 
Keamanan juga tercermin dalam kehidupan sehari-hari yang tidak ada konflik yang ekstrim. Dari data yang didapat berdasarkan hasil observasi, secara keseluruhan responden memberikan jawaban iya kategori merasa aman di wilayah UPT. Dalam pengkategorian jawaban, terdapat dua kategori jawaban yaitu: tidak aman, dan aman. Keamanan yang terwujud di lingkungan UPT memberikan kenyamanan dan ketenangan warga untuk melakukan aktivitas sehari-hari dan untuk melakukan pengupayaan peningkatan pendapatan.

\section{Kemandirian}

Sumodiningrat

mengemukakan tiga kategori mandiri yaitu kemandirian material, kemandirian intelektual, dan kemandirian manajemen. Kemandirian material merupakan kemampuan produktif guna memenuhi kebutuhan dasar pada waktu krisis. Kemandirian intelektual merupakan pembentukan dasar pengetahuan yang memungkinkan mereka menanggulangi bentuk-bentuk dominasi dari pihak luar. Kemandirian manajemen merupakan kemampuan untuk membina diri dan menjalani serta mengelola kegiatan kolektif.

Warga transmigran, apabila dipandang dari segi komunitas, mereka merupakan kumpulan orang-orang yang memiliki pekerjaan sebagai petani. Dengan adanya pendampingan maka warga transmigran diberi pendidikan dan pendampingan agar kapabilitasnya dapat bertambah dan berkembang. Peningkatan kapabilitas inilah yang diharapkan agar warga dapat melakukan segala aktifitas dan pemenuhan kebutuhannya dilakukan dengan kemampuan sendiri.

Jiwa mandiri yang tumbuh dikalangan warga transmigran diantaranya dapat dilihat dari upaya pengembangan lingkungan rumah tinggal, misalnya dalam hal pengembangan rumah hunian dan halaman rumah. Selain itu juga dalam hal pengadaan barang kebutuhan rumah tangga seperti pengadaan kompor gas, lemari, kursi, dan barang-barang rumah tangga lainnya yang pada penempatan awal tidak diberikan.

Jika dipandang dari sisi yang lain lagi warga transmigrasi juga sudah mandiri seperti halnya sudah lepas dari 
bantuan sandang dan pangan yang diberikan oleh pemerintah, karena bantuan yang diterima oleh warga transmigran hanyalah pada tahun pertama mereka memasuki lokasi transmigrasi saja setelah tahun selanjutnya mereka berusaha memenuhi kebutuhan hidup dan makan sendiri. Kemandirian ini juga dapat dijadikan tolak ukur untuk menentukan kesejahteraan.

\subsection{Faktor Yang Mempengaruhi} Perkembangan

Tingkat

Kesejahteraan Warga Transmigrasi

Sebelum Mereka Menjadi Warga

Transmigran Dan Setelah Meraka Menjadi Warga Transmigran

\section{Tinkat Pendapatan}

Pendapatan yang diterima warga transmigrasi lebih besar jika dibandingkan dengan sebelum mereka menjadi warga transmigrasi dan masih berada di tempat asal mereka. Beda tingkat pendapatan ini dapat dilihat pada tabel di bawah di mana 37 responden atau sebesar $82.2 \%$ menjawab iya, yang berarti pendapatan mereka lebih besar saat mereka telah menjadi warga transmigrasi jika di bandingkan dengan sebelum menjadi warga transmigrasi.

Pendapatan yang lebih tinggi ini juga di sebabkan oleh lamanya hari kerja mereka yang di tunjang oleh banyaknya lahan pekerjaan. Warga sekitar lokasi transmigrasi yang merupakan pemilik kebun membutuhkan tenaga para warga transmigran untuk pemeliharaan dan perawatan kebun mereka belum lagi pabrik gula yang membutuhkan tenaga mereka pada saat-saat tertentu, seperti halnya pada saat musim panen tebu maupun pada saat musim tanam dan pemupukan tebu.

Selain dari beberapa hal di atas pendapatan yang lebih tinggi ini juga dikarenakan warga transmigran yang dapat menjual hasil tanaman mereka dari lahan yang telah mereka garap seperti halnya tanaman: cabai, ubi, ketela dan palawija atau buah-buahan yang lainnya yang mereka tanam di pekarangan rumah atau di lahan tanaman padi yang cara penanamannya secara tumpang sari.

\section{Lapangan Pekerjaan}


Sebagian besar lapangan pekerjaan masyarakat transmigrasi sama saat mereka belum menjadi warga transmigran dan setelah mereka menjadi warga transmigran yakni menjadi buruh serabutan. Walau dalam hal ini tidak selalu menjadi buruh serabutan di bidang pertanian namun juga menjadi buruh serabutan di pasar atau di lokasi pembangunan, seperti halnya menjadi kuli pada pembangunan rumah.

Walaupun jenis pekerjaan mereka sama dan secara upah yang mereka dapat juga sama namun yang jadi pembeda di sini adalah lama hari kerja mereka jika pada sebelumnya warga hanya bekerja 10-15 hari dalam satu bulannya dikarenakan sulitnya mencari lahan pekerjaan dan banyaknya saingan yang ada pada wilah asal warga transmigran namun setelah mereka menjadi warga transmigran banyak lapangan pekerjaan yang tersedia pada sekitar lokasi tranmigrasi baik dari pemilik kebun di sekitar wilayah tranmigrasi maupun dari pabrik gula yang terdapat di dekat wilayah transmigrasi.

\section{Kepemilikan Aset}

Seperti halnya kita ketahui bahwa warga yang mengikuti program transmigrasi lokal ini akan mendapat aset berupa tanah untuk di kelola menjadi persawahan seluas 1 hektar dan mendapat $1 / 4$ hektar luas lahan yang digunakan untuk rumah beserta pekarangannya yang tentunya mereka juga mendapatkan rumah dan sudah ada sebagian warga yang sudah melakukan renovasi terhadap rumah mereka baik penambahan luasan dapur maupun bagian depan rumah seperti teras dan ruangan lainnya. Selain aset yang di dapat dari pemerintah sebagai bantuan kepada warga transmigrasi sebagian besar juga warga sudah ada yang mampu membeli barang yang berupa aset mereka. Walau bukan berbentuk perhiasan atau tanah di lokasi lain di luar wilayah transmigrasi namun aset yang mereka dapat beli dengan sendiri ini berupa kendaraan bermotor dan barang-barang elektronik yang ada dalam rumah mereka seperti halnya: televisi, radio dan yang lainnya yang dapat mereka jual kembali jika sewaktuwaktu mereka membutuhkan dana untuk keperluan mereka. 
Selain aset di atas warga transmigrasi juga memiliki aset berupa hewan ternak sapi yang mereka kelola secara swadaya dengan kelompok tani mereka. Ada sebagian warga transmigrasi juga sudah memiliki ternak secara perorangan walaupun baru berupa ayam dan bebek namun ternak ini sudah bisa mereka jual dan mereka jadikan uang jika terdapat kebutuhan yang mendesak akan uang.

Dari ketiga faktor di atas sudah menunjukkan bahwa sudah terjadi peningkatan taraf hidup warga transmigrasi menuju ke arah sejahtera. Walaupun pada perhitungan tingkat kemiskinan yang dilakukan pada pembahasan di atas masih menggolongkan warga transmigrasi ini ke dalam kategori miskin. Namun hal ini tidak terlalu dipermasalahkan oleh pemerintah Kabupaten Pringsewu, Lampung dikarenakan warga transmigrasi sudah dapat melangsungkan kehidupan mereka walau pendapat utama mereka masih dari menjadi buruh serabutan.

\section{KESIMPULAN}

1. Warga transmigrasi sudah dapat bertahan hidup dan menuju kehidupan yang lebih layak dengan bekerja sebagai buruh serabutan dan bertani dengan bibit yang diberikan pemerintah walau kondisi mereka masih berada pada garis kemiskinan.

2. Kebutuhan akan pekerjaan penghidupan yang layak. Dengan adanya pemberdayaan terhadap warga, khususnya dalam bidang pertanian dengan pengolahan bahan makanan. Dengan pekerjaan sebagai petani, warga sudah dapat bertahan untuk melangsungkan hidup.

3. Kebutuhan akan pendidikan juga dapat terpenuhi melalui pendampingan warga transmigran. Dengan pendampingan, warga diupayakan untuk meningkatkan pendidikannya.

4. Kebutuhan akan pengembangan diri. Warga transmigran mengalami peningkatan kapabilitas dalam bidang pertanian. Pengembangan diri ini merupakan cerminan jiwa mandiri warga transmigran. 
5. fasilitas pendidikan yang di sediakan pemerintah di lokasi transmigrasi membuat anak-anak warga lebih mudah untuk bersekolah dan mendapatkan pendidikan yang layak dan lebih tinggi.

\section{DAFTAR FUSTAKA}

Arman, Syamsuni. (2006). Transmigrasi dan Pluralitas. Artikel. Kompas, 18 September 2006. dan Kota Berbasis Pemberdayaan Komunitas. Depnakertrans.

Suharno, dkk. 1976. Transmigrasi Dan Latar Belakangnya. Bandung. LEKNAS-

LIPI Sardjadjaja, Rukman. (2009). Model Pembanguna Transmigrasi Dalam Pembangunan Sumberdaya Huatan. Jakarta Selatan. Lauser Cita Pustak.

Gustina, Nelvia. Peroses Sosial Antar Kelompok Etnis Di Permukiman Transmigrasi Spontan(skripsi). Fakultas Pertanian Institut Pertanian Bogor. Bogor

Heeren, H. J. (1979). Transmigrate In Indonesia. Jakarta. Gramedia. KH, Ramadhan. Hamid Jabbar, Rofiq Ahmad. 1993. Transmigrasi Harapan dan Tantangan. Departemen Transmigrasi RI. Jakarta.

Kolopaking, LM. (2006). Pengembangan Kawasan Perdesaan Transmigrasi Mandiri MacAndrew, Colin. \& Rahardjo. 1979. Pemukiman di Asia Tenggara dan
Transmigrasi di Indonesia. UGM. Gadjah Mada University Press. Noviarini, Tiara. (2018). Penguasaan Bahasa Pertama Pada Anak Transmigran Asal Jawa Di Air Haji Pesisir Selatan Sumatera Barat. JURNAL PESONA. 4. 32. 10.26638/jp.775.2080.

Rusli, Said. (1996). Pengantar Ilmu Kependudukan. Jakarta: LP3S

Suparno, Erman. (2007). Pidato Peringatan Hari Bhakti Transmigrasi Ke - 57 Tahun 2007. Diakases tanggal 27 Desember 2013. http://bto.sisfo.net.

Undang-undang Nomor 29 Tahun 2009 sebagai pengganti Undangundang Nomor 15 tahun 1997 tentang ketransmigrasian. 
Jurnal Parameter, Volume 3, No. 1 (2018)

ISSN : 1979-8865 